\title{
Enzymatic Activity of Mikromycetes Isolated from Thermal Water Sources of Azerbaijan
}

\author{
Konul F. Bakshaliyeva ${ }^{1 *}$, Nurlana N. Guliyeva ${ }^{2}$, \\ Sabiya M. Jabrailzade ${ }^{3}$ and Parvin M. Hashimova ${ }^{2}$ \\ ${ }^{1}$ Biological Sciences, Institute of Microbiology of ANAS, \\ Baku, Azerbaijan \\ ${ }^{2}$ Institute of Microbiology of the ANAS, Baku, Azerbaijan \\ ${ }^{3}$ Azerbaijan State Pedagogical University, Baku, Azerbaijan
}

*Corresponding author

\begin{tabular}{l} 
K e y w o r d s \\
$\begin{array}{l}\text { Greater Caucasus, } \\
\text { Micromycetes, } \\
\text { Hidrolytic enzymes, } \\
\text { Thermostability, } \\
\text { Bioconversion }\end{array}$ \\
\hline Article Info \\
$\begin{array}{l}\text { Accepted: } \\
\text { 20 June } 2019 \\
\text { Available Online: } \\
\text { 10 July } 2019\end{array}$ \\
\hline
\end{tabular}

\section{A B S T R A C T}

Aim of the present work was to study the species composition of fungi found in some thermal springs of Azerbaijan, and to evaluate them according to their activity of hydrolytic enzymes. This study shows that in the formation of mycobiota of thermal water sources of Azerbaijan, located in Greater Caucasus, takes part 22 species of fungi, $77.3 \%$ of which belongs to the division of Ascomycota, the others belongs to the division of Zygomycota. However, the mycobiots of individual thermal water sources are characterized by specific communities that differ in both quantitative and qualitative aspects, upon detection of which the main role is played the temperature and $\mathrm{pH}$ of sources. Many enzymes from micromycetes and macromycetes are characterized by relatively low thermostability, which is typical of enzymes synthesized for most of the mushrooms isolated from the thermal sources of Azerbaijan. However, the enzymes synthesized by the fungi Humicola lanuginosa, Mucor corymbifer and Mucor pusillus open up new perspectives for the use of their enzymes in various biotechnological processes, especially in the bioconversion of plant waste because, their enzymes systems are balanced by the activity of all enzymes catalyzing the main polymers that including in the composition of plant waste.

\section{Introduction}

Microorganisms, especially fungi are isolated group of organisms, which take place in circulation of different, as well as biogenic elements in different ecosystems $(4,12,21)$. The active role of fungi in these processes is conditioned by their high fermentative activity $(1,3)$ and with the ability to adapt to the physic-chemical and biological change parameters of the environment in a very short amount of time (4). There by in the process time they exit nearly everywhere, even in thermal sources, where the temperature is 
higher than pasteurization, $70^{\circ} \mathrm{C}$ (9). The study of fungi, spread in extreme conditions as well as in thermal sources is getting more attention lately, this is related with the clarifying the possibilities of the use of these microorganisms as a product of thermostable enzymes beside this (17, 19), this kind of researches can reveal their trophic relations in environmental compartments with high temperature gradient.

Thermal springs are widely spread in nature as well as in Azerbaijan light now there are 27 springs in Azerbaijan and they are in Azerbaijan part of Great Caucasus Mountain Range (12), Lesser Caucasus (3), and Talish Mountain Range (12). Different geochemical conditions determine the presence of the thermal waters of different compositions carbon dioxide, hydrogen sulfide, etc. the temperature of thermal waters of Azerbaijan vary form $32^{\circ} \mathrm{C}$ until $64^{\circ} \mathrm{C}(8)$.

Despite the fact that some authors consider thermal springs a classic habitat for thermophilic mycromycetes (19), but the study of fungi common in the thermal waters of Azerbaijan is still insufficient Since received data cannot unambiguous characterize neither specific structure, nor the enzymatic activity of fungi inhabiting in this places.

In this context, in aim of the present work was to study to species composition of fungi found in some thermal springs of Azerbaijan, and to evaluate them according to their activity of hydrolytic enzymes.

\section{Materials and Methods}

Researches were carried out on thermal water springs in the territory of Azerbaijan part of Great Caucasus Mountain Range. The choice of these areas based on the fact that all of these sources are located in mountainous areas and in comparison with other sources are less susceptible to anthropogenic impacts, they are more in a natural form.

In addition, the temperature of examined thermal water springs sources varies widely. The highest temperature source was Shikh $\left(65^{\circ} \mathrm{C}\right.$ Absheron Peninsula), and the lowest temperature sources was Khalkhal $\left(30^{\circ} \mathrm{C}\right.$, Oguz district). The $\mathrm{pH}$ of the thermal waters ranged from 7.3 (Gamazvan, Gabala district) to 9.0 Shikh (8).

Water samples for appropriate analyzes were taken in sterile container, stored in a refrigerator at $4^{\circ} \mathrm{C}(7)$.

Numerical composition of fungi was accounted considered using dilution method (1: 10) by counting the colonies grown on standard agar media (wort agar $40^{\circ} \mathrm{B}$ ) and their recalculating to absenteeism to the number of prologues (i.e. colony forming units $\mathrm{CFU}$ ) in $1 \mathrm{ml}$ of water. To characterize the structure of the fungi complex the frequency of occurrence has been used.

To determine the temperature optima of growth standard number of cell suspensions were grown in Erlenmeyer glasses of $250 \mathrm{ml}$ in a thermostat within $25^{\circ} \mathrm{C}-50^{\circ} \mathrm{C}$, and to study the $\mathrm{pH}$ environment in phosphate suffered within 6.0- 9.0 the growth of the fungi was evaluated by the growth of the biomass and measured bringing to constant weight at $105^{\circ} \mathrm{C}$.

The identification of fungi isolated in pure culture was carried out according to the determinant formed by their morphological and physiological characteristics (10-11, 13, $16,18)$.

In the study of the enzymatic activity of fungi, as a source of enzymes there have been used cultured liquid obtained by growth of the 
fungus on cezpek liquid medium for 5 days. The activity of endoglucanase and pectinase was determined by viscometer method, amylose by colorimetric method, protease by Anson method and xylanase on ShomodiNelson method $(5,15)$.

Thermostability of fungi enzymes was determined by the method used in the H.G. Ganbarov's and others study (6).

\section{Results and Discussion}

The results showed that micromycetes are the constant components of biota of investigated thermal sources, although their qualitative and quantitative composition greatly varies depending on ecological conditionstemperature and the $\mathrm{pH}$.

As can be seen both in quantitative and species composition the poorest micobiota is characterized by Shikh thermal springs, which is characteristically by high temperature and $\mathrm{pH}$. Similar data for Khalkhal source characterized by the highest values. Other sources occupy a middle position in terms of abundance and species composition.

It should be noted that from cell the investigated is sources species which belonged to 11 genera have been identified taxonomic structure of isolated fungi in the investigated thermal sources is presented. As can be seen, $22.7 \%$ of the detected fungi belong to zygomycota series group, the rest belong to Ascomycota series group, although most of the marsupials fungi $(54,6 \%)$ are anamorphic.

A comparison of the data with the result of mycological research conducted in Azerbaijan. Showed that the majority of fungi found in the thermal springs are common in the different ecosystems of the country. However there were fungi that until our research on the territory of Azerbaijan have not been found, these properties characterize fungus like Aspergillus carneus (Tiegh) Blochwitz, Mucor cornelis Cavara \& Sacc and Penicillium arenarium Shaposhnikav \& Manteifel.

It should also be noted that the mycobiota of all the investigated springs is not very rich both in number and in species composition. For example, in the formation of mycobiota of Barguziksky (Russia) alkaline thermal springs, under temperature $\left(33.5-69.5^{\circ} \mathrm{C}\right)$ and $\mathrm{pH}(8.2-9.7)$ is also characterized by similar figures, there attended species of 19 kinds and numerical figure was 130-9500 of $\mathrm{CFU} / \mathrm{ml}$.

Considering the fact that in natural ecosystems hydrolytic enzymes offungi play an important role, we further investigated the synthesis and some kinetic features of extracellular forms of hydrolytic enzymes in fungi, isolated from hot thermal springs of Azerbaijan.

The results showed that all the isolated strains of microscopic fungi exhibit hydrolase activity, although fungi differ from one another according to the level of activity of a particular enzyme. Furthermore, there was the only exception that the strains of the Saccharomyces thermantitonum fungus don't activate extracellular amylase.

Regardless of some differences fungi, Aspergillus niger $\mathrm{N}-12, \quad$ Chaetomium thermophile $\mathrm{N}-29$ and Humicola lanuginosa $\mathrm{N}-47$ are more promising producers of hydrolases, since the level of activity of all studied enzymes of hydrolytic type have been relatively high and as the result of screening they were chosen for further research, which were focused on optimizing the conditions for the manifestation of their maximum activity. When optimizing the carbon and nitrogen 
sources have been quantitatively clarified. Also the growth temperature, the initial $\mathrm{pH}$ of the medium, the method and the preparation of the inoculum has been clarified during optimizing. The result of this revision has allowed an increase in activity by $14-18 \%$. It should be noted that the activity of the enzymes of the studied fungi in no way lag behind the well-known producers, belonging to micro or to macromycetes (1-2). Manifestation of high activity in a simple culture medium composition (prepared on the basis of waste) displays them in a number of promising producers compared to most micromycetes. But enzymes synthesizing active producers, in turn must meet a number of requirements, one of which is associated with the relation of enzymes to high temperatures (6). It is not a secret that the thermostable enzymes (i.e., capable of operating with high activity at high temperatures) is of great practical importance for modern biotechnological industry. Therefore, the study of relationship of enzymes to temperature is a perspective direction of modern research in the field of microbiology and biotechnology $(1,17)$. The studies have shown that enzymes synthesized from fungi, isolated from thermal springs of Azerbaijan at $65^{\circ} \mathrm{C}$ is characterized by semiactivation at different times $\left(\tau_{1 / 2}\right)$ which is usually used to characterized the thermostability of enzymes. In addition, the results allow dividing the fungi into three groups:

Fungi, synthesizing thermosensitive hydrolytic enzyme. For this fungi $\tau_{1 / 2} \leq 35$ min. Enzymes, synthesized by Aspergillus flavus, A. niger, A.terreus, Candida albicans, Hancenula anamola, Paecelomyces variotii, Penicillium arenarium, P.chrysogenium, P.notatum, Mucor hiemalis and Rhizomucor miehei fungi, are characterized by this indicator.
Fungi synthesizing thermotolerant hydrolytic enzymes. Aspergillus candidus, A.fumigatus, A.carneus, Chaetomium thermophile, Mucor cornealis, Penicillium duponti, Saccharomyces thermantitonum, Torula thermantitonum fungi belong to this group, as time for semiactivation for enzyme synthetized by them are within 60-600 minutes, that's 60 minute $\geq \tau_{1 / 2} \leq 600$ minutes.

Fungi synthesizing thermostable hydrolytic enzymes. For this group of fungi semiactivation time is more than half of the day, ie 12 hours $\left(\tau_{1 / 2} \geq 720 \mathrm{~min}\right)$. The ability to synthetize such enzymes unique to fungi Humicola lanuginosa, Mucor corymbifer, Mucor pusillus.

The results showed that 22 species of fungi take part in the formation of mycobiota of thermal springs of Azerbaijan waters located in the Greater Caucasus, 77,3\% of which belongs to the division of Ascomycota, the others belongs to the division of Zygomycota. However, the mycobiots of individual thermal water sources are characterized by specific communities that differ in both quantitative and qualitative aspects, upon detection of which the main role is played the temperature and $\mathrm{pH}$ of sources. Many enzymes from micromycetes and macromycetes are characterized by relatively low thermostability, which is typical of enzymes synthesized for most of the mushrooms isolated from the thermal sources of Azerbaijan. However, the enzymes synthesized by the fungi Humicola lanuginosa, Mucor corymbifer and Mucor pusillus open up new perspectives for the use of their enzymes in various biotechnological processes, especially in the bioconversion of plant waste $(14,20)$ because, their enzymes systems are balanced by the activity of all enzymes catalyzing the main polymers that including in the composition of plant waste. 


\section{References}

1. Ahirwar S, Soni H, Prajapati BP, Kango N. (2017). Isolation and screening of thermophilic and thermotolerant fungi for production of hemicellulases from heated environments. Mycology, 8(3): 125-134

2. Bairagi S. (2016). Isolation, screening and selection of fungal strains for potential cellulase and xylanase production. Int $\mathbf{J}$ Pharm Sci Invent, 5(3): 1-6

3. Brahmachari G. Demain A.L. Adrio J.L. (2017). Biotechnology of microbial enzymes. Chappter, 11:267-298

4. Biodiversity of Fungi: Inventory and Monitoring Methods (2011). Ed.Gregoru M.Mueller, Mercedes S. Foster, Gerald F. Bills Elsevier Press., 776

5. Chitoshi Hatanaka and Yoshiaki Kobara (1980). Determination of Glucose by a Modification of Somogyi-Nelson Method Agric. Biol. Chem., 44 (12): 2943-2949.

6. Ganbarov Kh. G., Muradov P.Z., Nutsubidze N.N. Some features of enzyme preparations obtained from wood-destroying basidiomycetes of the genus Bjerkandera. Bulletin of the BSU, ser.nauk.o nature, 1998, № 1, p. 67-73.

7. Handbook of Mycological Methods. http://www.fao.org/fileadmin/user_upload/agns/ pdf/coffee/Annex-F.2.pdf

8. http://eco.gov.az/en/152-our-resources (Date of the application: 22/06.2019).

9. http://blog.excurspb.ru/russia/item/470termalnye-istochniki-rossii (Date of the application: 22/06.2019).

http://www.ascofrance.fr/uploads/forum_file/Hu e/Humber-RA-Chapter-V-Entomofungiidentification-0001.PDF

11. http://www.mycobank.org/MycoTaxo.aspx (Date of the application: 22.06.2019).

12. Khvedelidze R.M., Urushadze T.R., Kutateladze L.I., Tsiklauri N.D., Zakariashvili N.G., Aleksidze T.I. (2017). Amilase-producing micromycetes isolated from soils of South
Caucasus. Annals of Agrarian Science, 15, 3: 318-321

13. Kirk P. M., Cannon P. F., Minter D. W. (2008). Dictionary of the fungi.10th edn. CABI publishing. Wallingford (UK), 600.

14. Lin H., Sun M., Li J., Xu Q., Yang B., Wang Q., Xie W. et al., (2018). Purification and characterization of xylanase from spent mushroom compost and its application in saccharification of biomass wastes. BioRes. 13(1), 220-230.

15. Methods of determine enzymatic activity. (2013)./Ed. A.B. Vermelho, S. Couri. Rio-de Janeyro, 322

16. Samson R.A., Pitt J.I. (2000). Integration of modern taxonomic methods for Penicillium and Aspergillus classification. Amsterdam: Harwood Publishers, 510.

17. Saroj P., Manasa P., Narasimhulu K. (2018). Characterization of thermophilic fungi producing extracellular lignocellulolytic enzymes for lignocellulosic hydrolysis under solid-state fermentation. Bioresour. Bioprocess. 5: 31. https://doi.org/10.1186/s40643-018-02166

18. Satton D., Fothergill A., Rinaldi M. (2001). Determinant of pathogenic and conditionally pathogenic fungi. M: World, 486.

19. Satyanarayana T., Ragbukumar C., Sbiraji S. (2005). Extremophilic microbes: diversity and perspectives. Curr. Science, 89 (1):45-62

20. Yadav S.K. (2017). Technological advances and applications of hydrolytic enzymes for valorization of lignocellulosic biomass. Bioresour Technol https://doi.org/10.1016/j.biortech.2017.05.066

21. Walid Ellouze, Ahmad Esmaeili Taheri, Luke D. Bainard, Chao Yang, Navid Bazghaleh et al., (2014). Soil fungal resources in annual cropping systems and their potential for management. Biomed Res Int. 531824. doi: $10.1155 / 2014 / 531824$

\section{How to cite this article:}

Konul F. Bakshaliyeva, Nurlana N. Guliyeva, Sabiya M. Jabrailzade and Parvin M. Hashimova. 2019. Enzymatic Activity of Mikromycetes Isolated from Thermal Water Sources of Azerbaijan. Int.J.Curr.Microbiol.App.Sci. 8(07): 2473-2477.

doi: https://doi.org/10.20546/ijcmas.2019.807.304 